\title{
Alpha One Antitrypsin Deficiency: From Gene to Treatment
}

\author{
Alice M. Wood ${ }^{a}$ Robert A. Stockley ${ }^{b}$ \\ a Department of Medical Sciences, University of Birmingham and ${ }^{\mathrm{b}}$ Lung Investigation Unit, \\ University Hospitals Birmingham, Birmingham, UK
}

\section{Key Words}

$\alpha 1$-antitrypsin deficiency · Molecular biology · Genetics, population $\cdot$ Epidemiology, molecular $\cdot$ Biological therapy

\begin{abstract}
$\alpha 1$-antitrypsin deficiency is a genetic disorder which contributes to the development of chronic obstructive pulmonary disease, bronchiectasis, liver cirrhosis and panniculitis. The discovery of $\alpha 1$-antitrypsin and its function as an antiprotease led to the protease-antiprotease hypothesis, which goes some way to explaining the pathogenesis of emphy-
\end{abstract}

Previous articles in this series: 1. Contopoulos-loannidis DG, Kouri IN, loannidis JPA: Genetic predisposition to asthma and atopy. Respiration 2007;74:8-12. 2. Sztrymf B, Yaïci A, Girerd B, Humbert $\mathrm{M}$ : Genes and pulmonary arterial hypertension. Respiration 2007;74:123-132. 3. Southern KW: Cystic fibrosis and formes frustes of CFTR-related disease. Respiration 2007;74:241-251. 4. Morillas HN, Zariwala M, Knowles MR: Genetic causes of bronchiectasis: primary ciliary dyskinesia. Respiration 2007;74:252-263. 5. Notarangelo LD, Plebani A, Mazzolari E, Soresina A, Bondioni MP: Genetic causes of bronchiectasis: primary immune deficiencies and the lung. Respiration 2007;74:264-275. 6. Cottin V, Dupuis-Girod S, Lesca G, Cordier J-F: Pulmonary vascular manifestations of hereditary hemorrhagic telangiectasia (Rendu-Osler disease). Respiration 2007;74:361-378.

\section{KARGER}

Fax +41613061234 E-Mail karger@karger.ch www.karger.com
(C) 2007 S. Karger AG, Basel 0025-7931/07/0745-0481\$23.50/0

Accessible online at: www.karger.com/res sema. This article will review the clinical features of $\alpha 1$-antitrypsin deficiency, the genetic mutations known to cause it, and how they do so at a molecular level. Specific treatments for the disorder based on this knowledge will be reviewed, including $\alpha 1$-antitrypsin replacement, gene therapy and possible future therapies, such as those based on stem cells.

Copyright $\odot 2007$ S. Karger AG, Basel

\section{Introduction}

$\alpha 1$-antitrypsin deficiency (AATD) was first described in 1963 by Laurell and Eriksson [1], who reported an absence of the $\alpha 1$-band on protein electrophoresis of serum taken from a patient at a local respiratory hospital. The observation that people with this deficiency develop early-onset emphysema [2] and chronic obstructive pulmonary disease (COPD) suggested a role for pathways involving $\alpha 1$-antitrypsin (AAT) in the pathogenesis. The main function of AAT is to protect the tissues against neutrophil elastase (NE) [3], with a smaller role in defending against damage by other serine proteases, such as cathepsin $G$ and proteinase 3. These enzymes induce emphysema and bronchial damage in animal models [4-6], giving rise to the protease-antiprotease hypothesis of disease in man. This theory suggests that

Prof. R.A. Stockley

Lung Investigation Unit, University Hospitals Birmingham

Birmingham B15 2TH (UK)

Tel. +44 121697 8257, Fax +44 121697 8256, E-Mail rob.stockley@uhb.nhs.uk 
when there is an imbalance of proteases (which digest elastin and other components of the extracellular matrix as well as damaging epithelial tissues) and protective antiproteases, excess damage occurs, manifesting as emphysema and COPD [7]. AATD can therefore be used as a disease model for COPD; thus research into the condition has led to and complemented much of the work in usual COPD. This has implicated other proteases in the pathogenesis of usual COPD, such as the matrix metalloproteinases [8], lending further support to the protease-antiprotease hypothesis, perhaps as part of an integrated cascade [9].

AAT is an acute-phase glycoprotein, synthesised in hepatocytes [10] and subsequently secreted into the plasma. It is also produced in smaller quantities by alveolar macrophages, circulating monocytes [11] and possibly lung epithelial cells $[12,13]$. Figure 1 shows the structure of AAT, highlighting some of the features that classify it as part of the serpin family of proteins, whose structure is based on $3 \beta$-sheets and a mobile reactive loop which acts as a binding site for the target protease $[14,15]$.

For AAT, the target protease is predominantly NE, though it can also bind irreversibly to proteinase 3 and cathepsin G. Point mutations in its mobile domain can lead to polymerisation of the protein within the liver [16], such that it is not secreted effectively into the plasma, resulting in low levels within the lung and vulnerability to NE-induced damage. Mutations like these underlie the most common forms of AATD, and ultimately are caused by genetic polymorphisms, thus providing a target for gene therapy that might cure the disease. However, amongst subjects with the same AAT genotype there is considerable variation in the clinical manifestations of the disease [17], even after taking into account environmental influences, such as smoking. This suggests that there are other genetic factors influencing disease susceptibility, meaning that AATD can also be a model for complex genetic diseases. This review will describe the genetic basis of AATD, clinical features of the disease and approaches to treatment derived from this knowledge.

\section{The Genetics of AATD}

The AAT protein is 394 amino acids in size, with the active site residue being methionine at position 358 (fig. 1). It is encoded by the protease inhibitor (Pi) locus on chromosome 14q [18-20]. The Pi locus (fig. 2) is 12.2

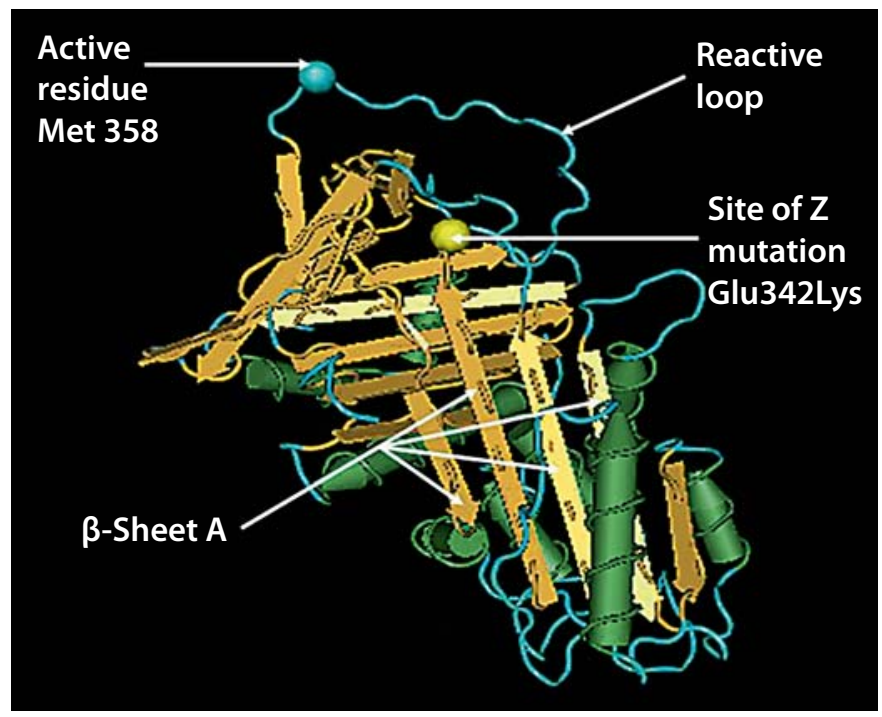

Fig. 1. The structure of AAT.

$\mathrm{kb}$ in length with 4 coding exons (II, III, IV, V), 3 noncoding exons (IA, IB, IC) and 6 introns; the region coding for the reactive loop is within exon V. It has been fully sequenced and cloned [21] and shows a co-dominant pattern of inheritance [2]. It is a highly pleomorphic gene with approximately 125 single nucleotide polymorphisms (SNPs) reported in public databases [22], a proportion of which have an effect on AAT level or function. Traditionally, each variant is identified by its speed of migration on gel electrophoresis, the most common forms being $\mathrm{F}$ (fast), $\mathrm{M}$ (medium), S (slow) and $\mathrm{Z}$ (very slow) [23]. Alteration in the speed of movement through a gel occurs because of variation in protein charge, due to changes in amino acid composition [24]. The PiM allele is the wild type, and is the most prevalent. The PiZ allele is a more common deficiency variant in northern Europeans, whilst the PiS deficiency variant is more common in south-west Europe [25]. A detailed review of their frequencies worldwide has been published previously [25].

Variants may also be classified by their effect on AAT level and function - normal, deficient, null (nil detectable) or dysfunctional. Deficient subjects are prone to lung or liver disease, whilst those carrying null alleles are prone only to lung disease. Serum deficiency or absence of AAT occurs because of alterations in gene expression or translation, or abnormal intracellular processing. Dysfunctional alleles code for an abnormal form of AAT, which, whilst present at a detectable level, does not func- 


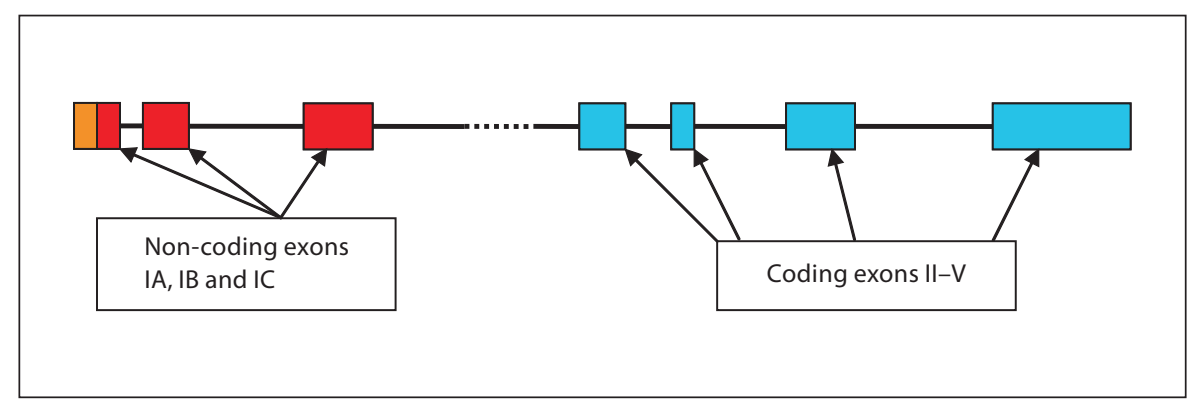

Fig. 2. The structure of the AAT gene.

Table 1. Effects of genetic variation within the Pi locus

\begin{tabular}{llll}
\hline Allele & Genetic defect & Cellular defect & Disease association \\
\hline $\mathrm{Z}$ & 1-bp substitution & intracellular aggregation & lung, liver \\
$\mathrm{S}$ & 1-bp substitution & intracellular aggregation & lung \\
Mmalton & 3-bp deletion & intracellular aggregation & lung, liver \\
Siiyama & 1-bp substitution & intracellular aggregation & lung \\
Mprocida [42] & 1-bp substitution & intracellular degradation & lung \\
Mheerlen [43, 44] & 1-bp substitution & intracellular degradation & lung \\
QOgranite falls & 1-bp deletion & unstable mRNA & lung \\
QOhong kong & 2-bp deletion & truncated protein & lung \\
QOisola di procida & deletion exons II-IV & no mRNA & lung \\
Pimineral springs & 1-bp substitution & poor inhibition of NE & lung \\
PiPittsburgh & 1-bp substitution & antithrombin III activity & bleeding diathesis \\
\hline
\end{tabular}

tion normally (such as the F variant). The majority of clinical disease due to AAT is from deficiency and null alleles.

The PiZ mutation is an SNP which results in an amino acid substitution - from glutamic acid to lysine - at position 342 (Glu342Lys), shown in figure 1. This causes a conformational change in the reactive loop that opens up $\beta$-sheet $A$ and allows the reactive loop of a second molecule to insert at this point [15]. This process extends to form AAT polymers, which form inclusion bodies in hepatocytes, rather than being secreted into the circulation, a process which has been reproduced in vitro under physiological conditions [16]. This process causes hepatocyte death and ultimately liver disease in AATD, though the precise mechanisms for this are not well understood. In addition, the expression of liver disease varies widely, from jaundice only at birth, through to cirrhosis, perhaps because of other genetic influences on this aspect of the clinical phenotype [26]. Polymerisation of AAT in this way also underlies the PiMmalton (52Phe deleted) [27] and Siiyama (Ser53Phe) [28-30] forms of
AATD, that are common in Sardinia and Japan, respectively. A slower rate of polymer formation occurs with the PiS allele (Glu264Val), because the structural change in $\beta$-sheet $A$ is not as radical $[31,32]$, resulting in a milder serum deficiency but little evidence of clinical disease. If an individual has the genotype PiSZ, then their clinical phenotype for liver disease [32] and lung disease in smokers [33] is usually intermediate between that of PiZ and PiS subjects.

Many null-allelic variants have been described which result in an absence of AAT, and are denoted as QO rather than Pi. A deletion of a single base pair leads to the QOgranite falls genotype, resulting in a premature stop codon and unstable mRNA [34]. Deletion of $2 \mathrm{bp}$ in exon IV characterises QOhong kong, which similarly has a premature stop codon, and hence a truncated protein [35]. This protein is retained in the endoplasmic reticulum of the liver accounting for the absence of the protein in the serum. Three other null alleles have been described, which also result in the formation of stop codons either due to substitution, deletion or addition of base(s) in cod- 
ing regions [36-38]. A larger deletion, comprising $17 \mathrm{bp}$, including exons II-IV is seen in the QOisola di procida allele, and is so substantial that no detectable mRNA or protein is produced [39].

Amongst the dysfunctional proteins described, those associated with poor inhibition of NE may be associated with lung disease. An example of this is Mmineral springs [40] caused by an SNP that leads to a single amino acid substitution (Gly67Glu) with intracellular aggregation of AAT; the latter characteristic means that it is also associated with serum deficiency. A different amino acid substitution at the active site (Met358Arg), known as PiPittsburgh, not only leads to reduced anti$\mathrm{NE}$ activity, but also to an anticoagulant effect by way of inhibition of factor IXa, kallikrein and factor XIIf [41]. Some of the polymorphisms discussed here are summarised in table 1.

\section{Genetic and Environmental Interactions}

AATD is a good example of a genetic disease where there is significant genotype-environment interaction. This is defined as a non-additive contribution of gene and environment to the clinical phenotype [45]; thus, together the 2 influences confer a different level of risk than that expected by addition alone. In AATD, for example, the PiZ phenotype confers a far greater risk of lung function abnormalities and rapidity of decline in smokers than in non-smokers $[46,47]$ because of the neutrophilic inflammation and consequent NE release, induced in the airways by cigarette smoke [7]. Similarly, in pulmonary arterial hypertension there may be an interaction between fenfluramine exposure and genotype that influences disease development [48]. Other respiratory diseases thought to have multiple genetic influences on phenotype include asthma [49] and sarcoidosis [50]. If these genes have additive or synergistic effects, these are referred to as epistatic interactions. In AATD there is some evidence that as yet unknown genes contribute to the clinical phenotype, as there is familial clustering of spirometric abnormalities in PiZ and PiMZ subjects $[51,52]$ and declining lung function in PiMZ individuals [53].

Genetic epidemiology studies in usual COPD have revealed many candidate genes [54], which may be contributing to disease in subjects who also have AATD. Casecontrol studies looking for these effects in AATD have not been widely published, but have implicated a polymorphism in the gene coding for endothelial nitric oxide synthase (NOS) 3 and an SNP in the glutathione $\mathrm{S}$ transferase P1 gene (GSTP1) [55]. The NOS3 SNP was shown to have a significant correlation with severity of lung disease, defined by $\mathrm{FEV}_{1}$ [56]. However, the authors were unable to show any functional variation in NOS3 with this SNP, and concluded that it must lie in linkage disequilibrium with another gene that caused the association. The GSTP1 SNP is an $A \rightarrow G$ change at nucleotide +313 , resulting in a single amino acid substitution (Ile105Val) [57] shown to increase the metabolism of carcinogenic aromatic epoxides [58]. Studies of the relationship of this variant to lung disease have also varied in their results. It would be expected that the 105Ile variant would be associated with higher levels of lung damage, since it is less active against oxidants, but in AATD this was not found to be the case [55]. Further family and casecontrol studies are underway and may begin to clarify reasons for phenotypic heterogeneity in AATD.

\section{Clinical Features of AATD}

AATD is associated with emphysema, chronic bronchitis, bronchiectasis, neonatal jaundice, liver cirrhosis, vasculitis and panniculitis [17]. The diagnosis of AATD will usually be made after investigation of these conditions, but is influenced by local and national practice, particularly with regard to neonatal and family screening. The PiZ allele is carried at a frequency of $0.5-4 \%$ in Europe, being more common in northern Europe [25]. Potential deficiency alleles (both PiZ and PiS) have been estimated to occur in 10\% of cases of COPD in Caucasians in the USA [59]. Allele frequency studies may not be as useful as genotype studies, however, as PiMS heterozygotes are not thought to be at risk of disease [60] and PiMZ subjects only have a small risk of developing COPD relative to PiMM individuals and may never have clinically significant problems [61]. A more recent review of genotype frequencies has suggested that in Europe the PiZZ genotype occurs in approximately 1 in 25 individuals in the UK, with the PiMZ genotype occurring in 1 in 2,000 individuals [62]. Studies of these genotypes amongst patients with a diagnosis of COPD have shown a prevalence of 1-4.5\% for PiZZ and up to $17.8 \%$ for PiMZ [60].

In a recent survey of over 5,000 American patients registered with AATD support groups, $81 \%$ exhibited symptoms of chest disease, including asthma, chronic bronchitis and emphysema [63]. This may reflect a selection bias, as those without symptoms are less likely to 
be diagnosed [64]. In our UK AATD cohort, $65 \%$ of subjects have been diagnosed after investigation of chest symptoms, with the majority of the remainder being ascertained through family screening [unpubl. data]. Many of the symptoms of AATD are non-specific, with subjects experiencing cough, wheeze and chest infections which may contribute to the delay in diagnosis experienced by many patients, which is 5.6 years on average from onset of symptoms [65]. The classical presentation is similar to usual COPD, though often at a younger age, or with less smoke exposure [17] and in the UK, current national guidelines only suggest testing for the condition in these groups [66]. Nevertheless, many patients present at an older age, like usual COPD, and thus testing for AATD should be considered in all patients with COPD.

Lung function tests usually show features typical of usual COPD, such as airflow obstruction with or without low gas transfer, and increased lung volumes. However, it is not uncommon for changes more usually associated with asthma, such as reversibility after bronchodilators, to be seen. In the National Heart, Lung, and Blood Institute AATD registry, reversibility of at least $12 \%$ in $\mathrm{FEV}_{1}$ was present in $28 \%$ of subjects at their baseline assessment [67]. Normal lung function may also be seen, most often, but not exclusively, in asymptomatic subjects. Amongst our patients homozygous for the $\mathrm{Z}$ allele (PiZZ), 9.1\% have normal lung function at their baseline assessment; $59 \%$ of these were diagnosed through family screening and $12.2 \%$ were tested because of respiratory symptoms [unpubl. data].

Smoke exposure is likely to be the most important determinant of lung function, with differences detectable between smokers and non-smokers even at an age of 18 years [68], and a significant relationship between smoking and lung function decline in adults [69]. This is consistent with our own data where $29.9 \%$ of British PiZZ subjects who had never smoked had normal spirometry at baseline, compared to only $5.3 \%$ of those who had smoked [unpubl. data]. Other determinants of more rapid decline of lung function include male sex, low body mass index, frequent exacerbations and the severity of upper zone emphysema [70].

High-resolution computed tomography (HRCT) scanning is now widely used in the assessment of usual COPD and COPD due to AATD, with many advances having been made in recent years in the interpretation of the data generated from such images $[71,72]$. Scan images can be used to diagnose emphysema and bronchiectasis, their type and distribution, as well as making objective mea- sures of severity based on the density of the CT image [71]. Our own work has shown that emphysema distribution in AATD relates to lung function [73], though it is not yet known if this is also true in usual COPD. In contrast to usual COPD, most patients with AATD have lower zone-predominant emphysema on HRCT. This is not universal, however, and upper zone-dominant emphyse$\mathrm{ma}$, when diagnosed using both visual features and quantitative density measures, is present in $12.1 \%$ of PiZZ subjects in our registry [unpubl. data]. Specific tests for AATD include measuring the serum level of AAT, with a level of less than $11 \mu \mathrm{M}$ considered pathophysiologically important, and genotyping. Genotyping has the advantage that it will pick up null genes, rare deficiency alleles and forms of AATD where the level of the protein is normal, but it does not function as it should, such as the F variant.

\section{Approaches to Treatment}

At present, treatment for AATD depends on the individual presentation: for most subjects this will mean interventions targeted at COPD. Treatment approaches targeting the molecular basis of disease, rather than its consequences, have the potential to treat all aspects of the condition, and are the subject of much current research. Such approaches include AAT replacement, blocking the polymerisation process within hepatocytes and gene therapy. Alternatively, liver transplantation, by replacing the organ in which most AAT is made, returns AAT levels to normal. If this is performed prior to the development of lung disease, it offers a cure, but can only be used in those with end-stage liver disease, at present, due to the shortage of suitable organs and the implications of subsequent life-long immunosuppression.

\section{AAT Replacement}

Since serum deficiency of AAT, and hence reduced protection against $\mathrm{NE}$ in the lung, underlies the lung disease seen in AATD, a logical approach is to treat it by trying to raise the circulating level of AAT. In nonsmokers with the PiSZ phenotype, epidemiological studies have shown little or no increase in the risk of lung disease compared to controls [33], thus their level of AAT (typically 11-14 $\mu \mathrm{mol} / \mathrm{l}$ ) was taken to be the minimum needed to protect the lung from NE-mediated damage.

An early study showed that it was possible to obtain AAT from pooled plasma and administer it by weekly 
Table 2. Status of selected rAAT production systems

\begin{tabular}{lllll}
\hline Host & Protein location & Yield & Stage of testing & References \\
\hline E. coli & intracellular & up to $38 \mathrm{mg} / \mathrm{l}$ & animals & {$[94-97]$} \\
Yeasts & intracellular or secreted & up to $1,230 \mathrm{mg} / \mathrm{l}$ & animals & {$[98-100]$} \\
Insect cells & secreted & not reported & in vitro & {$[90]$} \\
Transgenic rice & secreted & $4.6-5.7 \mathrm{mg} / \mathrm{l}$ & animals & {$[101,102]$} \\
Transgenic mice & milk & $0.5-7 \mathrm{mg} / \mathrm{ml}$ & in vitro & {$[103]$} \\
& urine & up to $65 \mathrm{mg} / \mathrm{l}$ & & {$[104]$} \\
Transgenic rabbits & milk & $4 \mathrm{~g} / \mathrm{l}$ & in vitro & {$[105]$} \\
Transgenic sheep & milk & up to $35 \mathrm{~g} / \mathrm{l}$ & phase $\mathrm{I}^{1}$ & {$[91-93]$} \\
Transgenic goats & milk & $20 \mathrm{~g} / \mathrm{l}$ & in vitro & {$[106]$} \\
\hline
\end{tabular}

${ }^{1}$ Further trials abandoned.

intravenous infusion, resulting in a serum nadir level of AAT (sufficient to protect the lung) associated with an increase in anti-elastase activity in the lower respiratory tract, as measured in bronchoalveolar lavage fluid [74]. Although this study was small, it was enough for the product to gain a license for treatment of patients with the PiZ or null phenotypes [75] in the USA, Canada and parts of Europe. Observational work in the USA has since supported the use of AAT replacement, showing a slower decline in lung function in those with an $\mathrm{FEV}_{1}$ of $35-49 \%$ predicted when receiving AAT augmentation [76]. Similar work in Europe has concurred [77, 78], whilst a Canadian study reported a beneficial effect but failed to show the association with baseline $\mathrm{FEV}_{1}$ [79]. The only randomised study to date, carried out in Denmark and Holland, showed a trend towards a reduction in emphysema progression, quantified by CT scanning, but did not reach statistical significance [80]. However, it did indicate that a larger trial would be sufficiently powered to detect a significant difference over 2 years and such a study has been completed recently (results are awaited).

Inhaled AAT may be a more efficacious method of administration, since only a small proportion of intravenous AAT reaches the lung. Initial studies of aerosolised forms of plasma-derived and recombinant AAT have shown that twice daily administration can raise the concentration in the epithelial lining fluid to normal [81] and some can reach the interstitium in animal models [82], though at much lower concentrations relative to the epithelium [83]. This is because of minimal protein movement across the epithelial barrier [84]. Thus, although this route may not replenish the interstitium, AAT activity in the epithelial lining fluid would be of benefit in re- ducing NE-induced airway inflammation, thus indirectly protecting the interstitium by reducing neutrophil traffic. A murine model of COPD has supported the use of inhaled AAT in reducing emphysema severity [85], lending more credence to this therapeutic approach. Further work in this area is indicated to clarify any potential benefit for patients.

\section{Recombinant AAT}

Although AAT replacement therapy shows promise in slowing the progression of lung disease, new ways of obtaining the product must be found as the plasma-derived supply is variable in purity and activity [86], and is likely to be insufficient to meet demand. The human Pi gene has been expressed in a variety of hosts, but no recombinant therapeutic product has been licensed yet. Such a product would need to be safe, clinically efficacious and cost-effective.

Expression in Escherichia coli has been the most widely used system, but is problematic because the recombinant AAT (rAAT) is not glycosylated, which affects the folding of the protein, such that it aggregates more easily, has reduced activity and a shorter half-life in the blood after infusion [87]. Conjugation with polyethylene glycol prolongs the half-life of E. coli-derived rAAT, and may be a useful strategy for the future [88]. Yeasts have advantages over bacteria for the production of therapeutic proteins, as they do not produce endotoxins and can provide some post-translational modifications [87]. Problems still arise, however, because the glycosylation process in yeasts differs from that of humans, such that elongation of carbohydrates occurs, resulting in structures of high mannose content - a process known as hypermannosylation [89]. This could lead to immune responses in hu- 


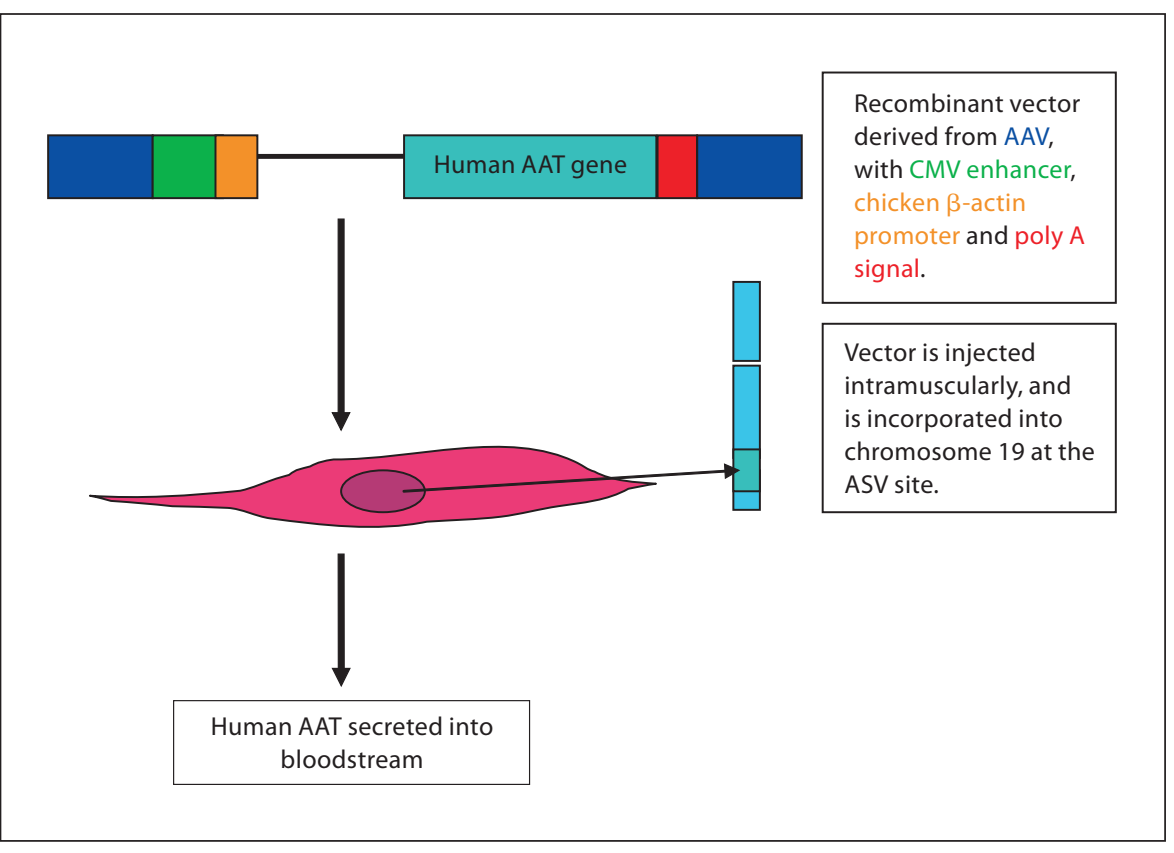

Fig. 3. Gene therapy in AATD.

mans because of non-human glycan residues, resulting in inactivation at best and allergic reactions at worst. Active rAAT has also been expressed in insect cells hosting baculovirus expression vector systems [90], again because of possible benefits in post-translational modification of the protein [87], but concerns regarding non-human glycans remain. Sources of rAAT from transgenic animals might overcome this problem, and are feasible for large-scale production [91, 92]. However, the first trial of inhaled rAAT from sheep milk reported a systemic antibody response, worse on repeated exposure, to the small a mounts of sheep AAT and $\alpha 1$-antichymotrypsin in the product [93]. The current status of rAAT production systems is shown in table 2.

\section{Therapies Targeting AAT Polymerisation and}

\section{Secretion}

The basic mechanism underlying both lung and liver disease in the most common forms of AATD is the accumulation of AAT in hepatocytes, with resultant serum deficiency. Polymerisation underlies accumulation in the $\mathrm{PiZ}$ form of AATD, and is initiated by protein misfolding, such that the $\mathrm{Z}$ form of AAT (Z-AAT) folds more slowly than the wild type [107], resulting in persistence of an intermediate form that is prone to polymer formation. If the processes underlying this can be altered, it may have clinically beneficial effects.

AATD: From Gene to Treatment
Chemical chaperones are a group of molecules that guide folding and may reverse cellular mislocalisation of proteins. Compounds known to have such activity include glycerol, trimethylamine $\mathrm{N}$-oxide and 4-phenylbutyric acid. Of these, 4-phenylbutyric acid has been shown to mediate an increase in secretion of Z-AAT in cell culture and murine models [108]. Trimethylamine N-oxide has been shown to stabilise native AAT [109], but did not prevent Z-AAT polymerisation in a cell culture model [108]. A more recent study has found a complex array of chaperones involved in the secretion of Z-AAT in vitro [110], although the significance is not yet known. Changes in intracellular degradation of Z-AAT were observed after the administration of drugs that interacted with these chaperones [110], suggesting more potential routes for drug development.

Precise inhibition of polymerisation of Z-AAT can also be achieved by annealing peptides to the reactive loop of $\beta$-sheet A. Initial studies used molecules 11-13 residues in length [16], but found that they were not specific for Z-AAT and hence could not be used for drug design. The same group of researchers has now assessed smaller peptides and shown them to be more specific, whilst still effective in blocking the process [111-113], thus allowing AAT to be released from the cells. Drugs developed from such molecules could help prevent liver disease due to accumulation in AATD. Unfortunately, if a peptide is bound to the molecule it also prevents AAT 
having any anti-elastase activity, hence it must be able to dissociate if it is also to provide protection to the lung. Parfrey et al. [113] have shown that some 6-mer peptides dissociate from Z-AAT under physiological conditions, with the dissociated material having some antiprotease activity, so further research of this approach may lead to useful therapies in the future.

\section{Gene Therapy}

This is the replacement of defective or absent genes within a cell such that the treated cell functions normally, and it is the most direct rationale for a genetic disorder such as AATD. Studies of gene therapy in animal models have used retroviral [114], adenoviral [115-119], adenoassociated viral [120-122] and liposomal [123, 124] vectors to transfect cells. Recombinant adeno-associated viral vectors have been the most successful delivery system thus far, as they are capable of achieving therapeutic levels of AAT $[120,121]$ and are less likely to induce an inflammatory response than adenoviral vectors. They also have a specific site for incorporation into the human genome (ASV site), thus giving the genetic material carried by the vector the potential for long-term expression.

A variety of routes of administration have been attempted for gene therapy. Initially, liver-directed therapy was attempted $[114,119]$, including portal vein injection of vector $[115,121]$, but this was impractical for use in humans. Airway instillation of vector suggested that inhaled or nebulised treatment might be a viable alternative $[116,124]$, but the most successful method so far has been intramuscular injection $[120,122]$. This system (fig. 3) is now entering phase II trials at the University of Florida [125], but may be hampered by the large doses of vector needed to achieve a therapeutic level of AAT. It should also be noted that such approaches, whilst potentially protecting the lung and other tissues, will not influence the liver disease.

\section{Stem Cells}

Research using stem cells has also shown some potential for treatment of AATD, though such approaches will require further development before clinical use. Stem cells can differentiate into liver cells capable of expressing AAT [126-128], thus, transplanting them into deficient patients might facilitate normal production of AAT. This would not prevent accumulation of polymers in the liver, however, so it would not necessarily affect liver manifestations of the disease. Alternatively, an approach targeting the lung might be used, as it is also possible to differentiate human embryonic stem cells into alveolar epithelial type II cells [129].

\section{Conclusion}

Knowledge of the genetics underlying common forms of AATD has generated several potential types of treatment. Although none are fully developed for human use, recombinant sources of AAT, chemical chaperones and gene therapy show promise for the future. Advances in genetic resources, such as the human genome project and HapMap [130, 131], and technology, including genome-wide scans, are making further research into genes which may be modifying the clinical phenotype in AATD more practical. Research in both the USA and Europe in this field could also lead to new targets for treatment, with potential for use in usual COPD as well as AATD.

\section{References}

1 Laurell CB, Eriksson S: The electrophoretic $\alpha 1$ globulin pattern of serum in $\alpha 1$ antitrypsin deficiency. Scand J Clin Lab Invest 1963; $15: 132-140$

2 Eriksson S: Studies in $\alpha 1$ antitrypsin deficiency. Acta Med Scand 1965;177(suppl): 432.

-3 Carrell RW, Jeppsson JO, Laurell CB, Brennan SO, Owen MC, Vaughan L, Boswell DR: Structure and variation of human $\alpha 1$-antitrypsin. Nature 1982;298:329-334.
4 Sloan B, Abrams WR, Meranze DR, Kimbel P, Weinbaum G: Emphysema induced in vitro and in vivo in dogs by a purified elastase from homologousleukocytes. Am Rev Respir Dis 1981;124:295-301.

5 Senior RM, Tegner H, Kuhn C, Ohlsson K, Starcher BC, Pierce JA: The induction of pulmonary emphysema with human leukocyte elastase. Am Rev Respir Dis 1977;116:469475.

-6 Snider GL, Lucey EC, Christensen TG, Stone PJ, Calore JD, Catanese A, Franzblau C: Emphysema and bronchial secretory cell metaplasia induced in hamsters by human neutrophil products. Am Rev Respir Dis 1984; 129:155-160.
7 Stockley RA: Neutrophils and protease/antiprotease imbalance. Am J Respir Crit Care Med 1999;160:S49-S52.

8 Shapiro SD, Senior RM: Matrix metalloproteinases: matrix degradation and more. Am J Respir Cell Mol Biol 1999;20:1100-1102.

9 Sullivan A, Stockley RA: Proteinases in COPD; in Hansel T, Barnes PJ (eds): Recent Advances in the Pathophysiology of COPD. Basel, Birkhäuser Verlag, 2004.

10 Koj A, Regoeczi E, Toews CJ, Leveille R, Gauldie J: Synthesis of antithrombin III and $\alpha 1$-antitrypsin by the perfused rat liver. Biochim Biophys Acta 1978;539:496-504. 
-11 Mornex JF, Chytil-Weir A, Martinet Y, Courtney M, LeCocq JP, Crystal RG: Expression of the $\alpha$-1-antitrypsin gene in mononuclear phagocytes of normal and $\alpha$-1-antitrypsin-deficient individuals. J Clin Invest 1986;77:1952-1961.

12 Venembre P, Boutten A, Seta N, Dehoux MS, Crestani B, Aubier M, Durand G: Secretion of $\alpha 1$-antitrypsin by alveolar epithelial cells. FEBS Lett 1994;346:171-174.

13 Cichy J, Potempa J, Travis J: Biosynthesis of $\alpha 1$-proteinase inhibitor by human lung-derived epithelial cells. J Biol Chem 1997;272: 8250-8255.

-14 Wilczynska M, Fa M, Karolin J, Ohlsson PI, Johansson LB, Ny T: Structural insights into serpin-protease complexes reveal the inhibitory mechanism of serpins. Nat Struct Biol 1997;4:354-357.

- 15 Elliott PR, Lomas DA, Carrell RW, Abrahams JP: Inhibitory conformation of the reactive loop of $\alpha 1$-antitrypsin. Nat Struct Biol 1996;3:676-681.

16 Lomas DA, Evans DL, Finch JT, Carrell RW: The mechanism of Z $\alpha 1$-antitrypsin accumulation in the liver. Nature 1992;357:605607.

$\checkmark 17$ Needham M, Stockley RA: $\alpha 1$-antitrypsin deficiency. 3. Clinical manifestations and natural history. Thorax 2004;59:441-445.

-18 Cox DW, Markovic VD, Teshima IE: Genes for immunoglobulin heavy chains and for $\alpha 1$-antitrypsin are localized to specific regions of chromosome 14q. Nature 1982;297: 428-430.

-19 Cox DW, Woo SL, Mansfield T: DNA restriction fragments associated with $\alpha 1$-antitrypsin indicate a single origin for deficiency allele PI Z. Nature 1985;316:79-81.

-20 Schroeder WT, Miller MF, Woo SL, Saunders GF: Chromosomal localization of the human $\alpha 1$-antitrypsin gene (PI) to $14 \mathrm{q} 31$ 32. Am J Hum Genet 1985;37:868-872.

-21 Lai EC, Kao FT, Law ML, Woo SL: Assignment of the $\alpha 1$-antitrypsin gene and a sequence-related gene to human chromosome 14 by molecular hybridization. Am J Hum Genet 1983;35:385-392.

22 Entrez SNP. http://www.ncbi.nlm.nih.gov/ projects/SNP/ (accessed 2006).

23 Fagerhol MK, Laurell CB: The Pi system-inherited variants of serum $\alpha 1$-antitrypsin. Prog Med Genet 1970;7:96-111.

$\checkmark 24$ Fagerhol MK, Laurell CB: The polymorphism of 'prealbumins' and $\alpha$-1-antitrypsin in human sera. Clin Chim Acta 1967;16:199203.

-25 Luisetti M, Seersholm N: $\alpha 1$-antitrypsin deficiency. 1. Epidemiology of $\alpha 1$-antitrypsin deficiency. Thorax 2004;59:164-169.

-26 Wu Y, Whitman I, Molmenti E, Moore K, Hippenmeyer P, Perlmutter DH: A lag in intracellular degradation of mutant $\alpha 1$-antitrypsin correlates with the liver disease phenotype in homozygous PiZZ $\alpha 1$-antitrypsin deficiency. Proc Natl Acad Sci USA 1994;91: 9014-9018.
27 Matsunaga E, Shiokawa S, Nakamura H, Maruyama T, Tsuda K, Fukumaki Y: Molecular analysis of the gene of the $\alpha 1$-antitrypsin deficiency variant, Mnichinan. Am J Hum Genet 1990;46:602-612.

-28 Seyama K, Nukiwa T, Souma S, Shimizu K, Kira S: $\alpha 1$-antitrypsin-deficient variant Siiyama (Ser53[TCC] to Phe53[TTC]) is prevalent in Japan: status of $\alpha 1$-antitrypsin deficiency in Japan. Am J Respir Crit Care Med 1995;152:2119-2126.

29 Seyama K, Nukiwa T, Takabe K, Takahashi H, Miyake K, Kira S: Siiyama (serine 53 (TCC) to phenylalanine 53 (TTC)): a new $\alpha 1$ antitrypsin-deficient variant with mutation on a predicted conserved residue of the serpin backbone. J Biol Chem 1991;266:1262712632.

-30 Lomas DA, Finch JT, Seyama K, Nukiwa T, Carrell RW: $\alpha 1$-antitrypsin Siiyama (Ser53 $\rightarrow$ Phe): further evidence for intracellular loop-sheet polymerization. J Biol Chem 1993;268:15333-15335.

31 Elliott PR, Stein PE, Bilton D, Carrell RW, Lomas DA: Structural explanation for the deficiency of $S \alpha 1$-antitrypsin. Nat Struct Biol 1996;3:910-911.

32 Mahadeva R, Chang WS, Dafforn TR, Oakley DJ, Foreman RC, Calvin J, Wight DG, Lomas DA: Heteropolymerization of S, I, and Z $\alpha 1$-antitrypsin and liver cirrhosis. J Clin Invest 1999;103:999-1006.

33 Turino GM, Barker AF, Brantly ML, Cohen AB, Connelly RP, Crystal RG, Eden E, Schluchter MD, Stoller JK: Clinical features of individuals with $\mathrm{PI}^{*} \mathrm{SZ}$ phenotype of $\alpha 1$ antitrypsin deficiency. $\alpha 1$-Antitrypsin Deficiency Registry Study Group. Am J Respir Crit Care Med 1996;154:1718-1725.

34 Nukiwa T, Takahashi H, Brantly M, Courtney M, Crystal RG: $\alpha 1$-antitrypsin null $_{\text {Granite Falls }}$, a nonexpressing $\alpha 1$-antitrypsin gene associated with a frameshift to stop mutation in a coding exon. J Biol Chem 1987; 262:11999-12004.

35 Sifers RN, Brashears-Macatee S, Kidd VJ, Muensch H, Woo SL: A frameshift mutation results in a truncated $\alpha 1$-antitrypsin that is retained within the rough endoplasmic reticulum. J Biol Chem 1988;263:7330-7335.

36 Fraizer GC, Siewertsen M, Harrold TR, Cox DW: Deletion/frameshift mutation in the $\alpha 1$-antitrypsin null allele, $\mathrm{PI}^{*} \mathrm{QObolton}$. Hum Genet 1989;83:377-382.

37 Curiel D, Brantly M, Curiel E, Stier L, Crystal RG: $\alpha 1$-antitrypsin deficiency caused by the $\alpha 1$-antitrypsin null Mattawa $_{\text {gene. An insertion }}$ mutation rendering the $\alpha 1$-antitrypsin gene incapable of producing $\alpha 1$-antitrypsin. J Clin Invest 1989;83:1144-1152.

38 Garver RI Jr, Mornex JF, Nukiwa T, Brantly M, Courtney M, LeCocq JP, Crystal RG: $\alpha 1$-antitrypsin deficiency and emphysema caused by homozygous inheritance of nonexpressing $\alpha 1$-antitrypsin genes. $\mathrm{N}$ Engl J Med 1986;314:762-766.
39 Takahashi H, Crystal RG: $\alpha 1$-antitrypsin null $_{\text {isola di procida: }}$ : an $\alpha 1$-antitrypsin deficiency allele caused by deletion of all $\alpha 1$-antitrypsin coding exons. Am J Hum Genet 1990;47: 403-413.

40 Curiel DT, Vogelmeier C, Hubbard RC, Stier LE, Crystal RG: Molecular basis of $\alpha 1$-antitrypsin deficiency and emphysema associated with the $\alpha 1$-antitrypsin $\mathrm{M}_{\text {mineral springs }}$ allele. Mol Cell Biol 1990;10:47-56.

-41 Scott CF, Carrell RW, Glaser CB, Kueppers F, Lewis JH, Colman RW: $\alpha$-1-antitrypsinPittsburgh: a potent inhibitor of human plasma factor XIa, kallikrein, and factor XIIf. J Clin Invest 1986;77:631-634.

42 Takahashi H, Nukiwa T, Satoh K, Ogushi F, Brantly M, Fells G, Stier L, Courtney M, Crystal RG: Characterization of the gene and protein of the $\alpha 1$-antitrypsin 'deficiency' allele $\mathrm{M}_{\text {procida. }}$ J Biol Chem 1988;263:1552815534.

43 Poller W, Merklein F, Schneider-Rasp S, Haack A, Fechner H, Wang H, Anagnostopoulos I, Weidinger S: Molecular characterisation of the defective $\alpha 1$-antitrypsin alleles PI Mwürzburg (Pro369Ser), Mheerlen (Pro369Leu), and Q0lisbon (Thr68Ile). Eur J Hum Genet 1999;7:321-331.

44 Hofker MH, Nukiwa T, van Paassen HM, Nelen M, Kramps JA, Klasen EC, Frants RR, Crystal RG: A Pro-Leu substitution in codon 369 of the $\alpha$-1-antitrypsin deficiency variant PI MHeerlen. Hum Genet 1989;81: 264-268.

45 Hartl D, Clark A: Principles of Population Genetics. Sunderland, Sinauer Associates, 1997.

$>46$ Janus ED, Phillips NT, Carrell RW: Smoking, lung function, and $\alpha 1$-antitrypsin deficiency. Lancet 1985;i:152-154.

47 Piitulainen E, Tornling G, Eriksson S: Effect of age and occupational exposure to airway irritants on lung function in non-smoking individuals with $\alpha 1$-antitrypsin deficiency (PiZZ). Thorax 1997;52:244-248.

48 Sztrymf B, Yaicci A, Girerd B, Humbert M: Genes and pulmonary arterial hypertension. Respiration 2007;74:123-132.

49 Contopoulos-Ioannidis DG, Kouri IN, Ioannidis JP: Genetic predisposition to asthma and atopy. Respiration 2007;74:8-12.

50 Grutters JC: Genetics of sarcoidosis: role of co-stimulatory genes? Respiration 2005;72: 227-228.

51 Silverman EK, Province MA, Campbell EJ, Pierce JA, Rao DC: Variability of pulmonary function in $\alpha$-1-antitrypsin deficiency: residual family resemblance beyond the effect of the Pi locus. Hum Hered 1990;40:340355.

52 Silverman EK, Province MA, Rao DC, Pierce JA, Campbell EJ: A family study of the variability of pulmonary function in $\alpha 1$-antitrypsin deficiency: quantitative phenotypes. Am Rev Respir Dis 1990;142:1015-1021. 
53 Sandford AJ, Chagani T, Weir TD, Connett JE, Anthonisen NR, Pare PD: Susceptibility genes for rapid decline of lung function in the lung health study. Am J Respir Crit Care Med 2001;163:469-473.

-54 Wood AM, Stockley RA: The genetics of chronic obstructive pulmonary disease. Respir Res 2006;7:130.

-55 Rodriguez F, de la Roza C, Jardi R, Schaper M, Vidal R, Miravitlles M: Glutathione Stransferase P1 and lung function in patients with $\alpha 1$-antitrypsin deficiency and COPD. Chest 2005;127:1537-1543.

-56 Novoradovsky A, Brantly ML, Waclawiw MA, Chaudhary PP, Ihara H, Qi L, Eissa NT, Barnes PM, Gabriele KM, Ehrmantraut ME, Rogliani P, Moss J: Endothelial nitric oxide synthase as a potential susceptibility gene in the pathogenesis of emphysema in $\alpha 1$-antitrypsin deficiency. Am J Respir Cell Mol Biol 1999;20:441-447.

- 57 Ali-Osman F, Akande O, Antoun G, Mao JX, Buolamwini J: Molecular cloning, characterization, and expression in Escherichia coli of full-length cDNAs of three human glutathione S-transferase Pi gene variants: evidence for differential catalytic activity of the encoded proteins. J Biol Chem 1997;272:1000410012.

-58 Sundberg K, Johansson AS, Stenberg G, Widersten M, Seidel A, Mannervik B, Jernstrom B: Differences in the catalytic efficiencies of allelic variants of glutathione transferase P1-1 towards carcinogenic diol epoxides of polycyclic aromatic hydrocarbons. Carcinogenesis 1998;19:433-436.

59 de Serres FJ, Blanco I, Fernandez-Bustillo E: Estimating the risk for $\alpha-1$ antitrypsin deficiency among COPD patients: evidence supporting targeted screening. COPD 2006;3: 133-139.

-60 American Thoracic Society/European Respiratory Society Statement: Standards for the Diagnosis and Management of Individuals with $\alpha-1$ Antitrypsin Deficiency. Am J Respir Crit Care Med 2003;168:818-900.

-61 Hersh CP, Dahl M, Ly NP, Berkey CS, Nordestgaard BG, Silverman EK: Chronic obstructive pulmonary disease in $\alpha 1$-antitrypsin PI MZ heterozygotes: a meta-analysis. Thorax 2004;59:843-849.

-62 Blanco I, de Serres FJ, Fernandez-Bustillo E, Lara B, Miravitlles M: Estimated numbers and prevalence of $\mathrm{PI}^{*} \mathrm{~S}$ and $\mathrm{PI}^{*} \mathrm{Z}$ alleles of $\alpha 1$ antitrypsin deficiency in European countries. Eur Respir J 2006;27:77-84.

-63 Strange C, Stoller JK, Sandhaus RA, Dickson $\mathrm{R}$, Turino G: Results of a survey of patients with $\alpha-1$ antitrypsin deficiency. Respiration 2006; $73: 185-190$

-64 Silverman EK, Pierce JA, Province MA, Rao DC, Campbell EJ: Variability of pulmonary function in $\alpha$-1-antitrypsin deficiency: clinical correlates. Ann Intern Med 1989;111: 982-991.
65 Stoller JK, Sandhaus RA, Turino G, Dickson $\mathrm{R}$, Rodgers K, Strange C: Delay in diagnosis of $\alpha 1$-antitrypsin deficiency: a continuing problem. Chest 2005;128:1989-1994.

66 Management of Chronic Obstructive Pulmonary Disease in Adults in Primary and Secondary Care. 2004. http://guidance.nice. org.uk/CG12/niceguidance/pdf/English (accessed 2006).

67 Eden E, Hammel J, Rouhani FN, Brantly ML, Barker AF, Buist AS, Fallat RJ, Stoller JK, Crystal RG, Turino GM: Asthma features in severe $\alpha 1$-antitrypsin deficiency: experience of the National Heart, Lung, and Blood Institute Registry. Chest 2003;123:765-771.

68 Piitulainen E, Sveger T: Effect of environmental and clinical factors on lung function and respiratory symptoms in adolescents with $\alpha 1$-antitrypsin deficiency. Acta Paediatr 1998;87:1120-1124.

69 Piitulainen E, Eriksson S: Decline in FEV related to smoking status in individuals with severe $\alpha 1$-antitrypsin deficiency (PiZZ). Eur Respir J 1999;13:247-251.

70 Dawkins PA, Dawkins CL, Stockley JA, Needham M, Stockley RA: Associations with annual decline in lung function in $\alpha$-1-antitrypsin deficiency. American Thoracic Society Conference, San Diego, 2006.

71 Shaker SB, Stavngaard T, Stolk J, Stoel B, Dirksen A: $\alpha 1$-antitrypsin deficiency. 7. Computed tomographic imaging in $\alpha 1$-antitrypsin deficiency. Thorax 2004;59:986-991.

72 Zompatori M, Laporta T: The heresy of one age becomes the orthodoxy of the next: what is new about detecting emphysema? Respiration 2007;74:133-135.

73 Parr DG, Stoel BC, Stolk J, Stockley RA: Pattern of emphysema distribution in $\alpha 1$-antitrypsin deficiency influences lung function impairment. Am J Respir Crit Care Med 2004;170:1172-1178.

74 Gadek JE, Klein HG, Holland PV, Crystal RG: Replacement therapy of $\alpha 1$-antitrypsin deficiency: reversal of protease-antiprotease imbalance within the alveolar structures of PiZ subjects. J Clin Invest 1981;68:11581165.

75 Wewers MD, Casolaro MA, Sellers SE, Swayze SC, McPhaul KM, Wittes JT, Crystal RG: Replacement therapy for $\alpha 1$-antitrypsin deficiency associated with emphysema. N Engl J Med 1987;316:1055-1062.

76 Survival and $\mathrm{FEV}_{1}$ decline in individuals with severe deficiency of $\alpha 1$-antitrypsin. The $\alpha 1$-Antitrypsin Deficiency Registry Study Group. Am J Respir Crit Care Med 1998;158: 49-59.

-77 Seersholm N, Wencker M, Banik N, Viskum K, Dirksen A, Kok-Jensen A, Konietzko N Does $\alpha 1$-antitrypsin augmentation therapy slow the annual decline in $\mathrm{FEV}_{1}$ in patients with severe hereditary $\alpha 1$-antitrypsin deficiency? Wissenschaftliche Arbeitsgemeinschaft zur Therapie von Lungenerkrankungen (WATL) $\alpha 1$-AT Study Group. Eur Respir J 1997;10:2260-2263.
78 Wencker M, Fuhrmann B, Banik N, Konietzko N: Longitudinal follow-up of patients with $\alpha_{1}$-protease inhibitor deficiency before and during therapy with IV $\alpha_{1}$-protease inhibitor. Chest 2001;119:737-744.

79 Chapman KR, Bradi AC, Paterson D, Navickis RA, Wilkes MM: Slower lung function decline during augmentation therapy in patients with $\alpha$-1-antitrypsin deficiency: results from the Canadian AIR registry. American Thoracic Society Conference, San Diego, 2005.

80 Dirksen A, Dijkman JH, Madsen F, Stoel B, Hutchison DC, Ulrik CS, Skovgaard LT, Kok-Jensen A, Rudolphus A, Seersholm N, Vrooman HA, Reiber JH, Hansen NC, Heckscher T, Viskum K, Stolk J: A randomized clinical trial of $\alpha_{1}$-antitrypsin augmentation therapy. Am J Respir Crit Care Med 1999; 160:1468-1472.

81 Hubbard RC, Brantly ML, Sellers SE, Mitchell ME, Crystal RG: Anti-neutrophil-elastase defenses of the lower respiratory tract in $\alpha 1$ antitrypsin deficiency directly augmented with an aerosol of $\alpha 1$-antitrypsin. Ann Intern Med 1989;111:206-212.

82 Hubbard RC, Crystal RG: Strategies for aerosol therapy of $\alpha 1$-antitrypsin deficiency by the aerosol route. Lung 1990;168(suppl): 565-578.

83 Smith RM, Traber LD, Traber DL, Spragg RG: Pulmonary deposition and clearance of aerosolized $\alpha$-1-proteinase inhibitor administered to dogs and to sheep. J Clin Invest 1989;84:1145-1154

84 Gorin AB, Stewart PA: Differential permeability of endothelial and epithelial barriers to albumin flux. J Appl Physiol 1979;47: 1315-1324.

85 Pemberton PA, Kobayashi D, Wilk BJ, Henstrand JM, Shapiro SD, Barr PJ: Inhaled recombinant $\alpha 1$-antitrypsin ameliorates cigarette smoke-induced emphysema in the mouse. COPD 2006;3:101-108.

86 Cowden DI, Fisher GE, Weeks RL: A pilot study comparing the purity, functionality and isoform composition of $\alpha$-1-proteinase inhibitor (human) products. Curr Med Res Opin 2005;21:877-883.

87 Karnaukhova E, Ophir Y, Golding B: Recombinant human $\alpha-1$ proteinase inhibitor: towards therapeutic use. Amino Acids 2006; 30:317-332.

-88 Cantin AM, Woods DE, Cloutier D, Dufour EK, Leduc R: Polyethylene glycol conjugation at Cys 232 prolongs the half-life of $\alpha 1$ proteinase inhibitor. Am J Respir Cell Mol Biol 2002;27:659-665.

89 Fukada M: Cell surface carbohydrates: cell type-specific expression; in Fukada $\mathrm{M}$, Hinghaul O (eds): Molecular and Cellular Glycobiology. New York, Oxford University Press, 2000, pp 12-61. 
90 Sandoval C, Curtis H, Congote LF: Enhanced proliferative effects of a baculovirus-produced fusion protein of insulin-like growth factor and $\alpha_{1}$-proteinase inhibitor and improved anti-elastase activity of the inhibitor with glutamate at position 351 . Protein Eng 2002;15:413-418.

$\checkmark 91$ Carver AS, Dalrymple MA, Wright G, Cottom DS, Reeves DB, Gibson YH, Keenan JL, Barrass JD, Scott AR, Colman A, et al: Transgenic livestock as bioreactors: stable expression of human $\alpha$-1-antitrypsin by a flock of sheep. Biotechnology (NY) 1993; 11:1263-1270

$\checkmark 92$ Wright G, Carver A, Cottom D, Reeves D, Scott A, Simons P, Wilmut I, Garner I, Colman A: High level expression of active human $\alpha$-1-antitrypsin in the milk of transgenic sheep. Biotechnology (NY) 1991;9: 830-834.

-93 Spencer LT, Humphries JE, Brantly ML: Antibody response to aerosolized transgenic human $\alpha 1$-antitrypsin. N Engl J Med 2005;352:2030-2031.

\$4 Bischoff R, Speck D, Lepage P, Delatre L, Ledoux C, Brown SW, Roitsch C: Purification and biochemical characterization of recombinant $\alpha 1$-antitrypsin variants expressed in Escherichia coli. Biochemistry 1991;30:3464-3472.

-95 Bottomley SP, Stone SR: Protein engineering of chimeric Serpins: an investigation into effects of the Serpin scaffold and reactive centre loop length. Protein Eng 1998; 11:1243-1247.

$\checkmark 96$ Courtney M, Buchwalder A, Tessier LH, Jaye M, Benavente A, Balland A, Kohli V, Lathe R, Tolstoshev P, Lecocq JP: High-level production of biologically active human a1-antitrypsin in Escherichia coli. Proc Natl Acad Sci USA 1984;81:669-673.

97 Karnaukhova E, Ophir Y, Golding B, Shrake A: Recombinant human $\alpha 1$ proteinase inhibitor: glycosylation, stability and biological activity. 10th FDA Science Forum: The Critical Path from Concept to Consumer, Washington DC, 2004.

\$8 Casolaro MA, Fells G, Wewers M, Pierce JE, Ogushi F, Hubbard R, Sellers S, Forstrom J, Lyons D, Kawasaki G, et al: Augmentation of lung antineutrophil elastase capacity with recombinant human $\alpha$-1-antitrypsin. J Appl Physiol 1987;63:2015-2023.

99 Kwon KS, Song M, Yu MH: Purification and characterization of $\alpha 1$-antitrypsin secreted by recombinant yeast Saccharomyces diastaticus. J Biotechnol 1995;42:191-195.

-100 Tamer IM, Chisti Y: Production and recovery of recombinant protease inhibitor $\alpha 1$ antitrypsin. Enzyme Microb Technol 2001; 29:611-620.

-101 Terashima M, Ejiri Y, Hashikawa N, Yoshida $\mathrm{H}$ : Effects of sugar concentration on recombinant human $\alpha_{1}$-antitrypsin production by genetically engineered rice cell. Biochem Eng J 2000;6:201-205.
102 Huang J, Sutliff TD, Wu L, Nandi S, Benge K, Terashima M, Ralston AH, Drohan W, Huang N, Rodriguez RL: Expression and purification of functional human $\alpha 1$-antitrypsin from cultured plant cells. Biotechnol Prog 2001;17:126-133.

103 Archibald AL, McClenaghan M, Hornsey V, Simons JP, Clark AJ: High-level expression of biologically active human $\alpha 1$-antitrypsin in the milk of transgenic mice. Proc Natl Acad Sci USA 1990;87:5178-5182.

104 Zbikowska HM, Soukhareva N, Behnam R, Lubon H, Hammond D, Soukharev S: Uromodulin promoter directs high-level expression of biologically active human $\alpha 1$ antitrypsin into mouse urine. Biochem J 2002;365:7-11.

105 Massoud M, Bischoff R, Dalemans W, Pointu H, Attal J, Schultz H, Clesse D, Stinnakre MG, Pavirani A, Houdebine LM: Expression of active recombinant human $\alpha 1$-antitrypsin in transgenic rabbits. J Biotechnol 1991;18:193-203.

106 Ziomek CA: Commercialization of proteins produced in the mammary gland. Theriogenology 1998;49:139-144

107 Yu MH, Lee KN, Kim J: The Z type variation of human $\alpha 1$-antitrypsin causes a protein folding defect. Nat Struct Biol 1995;2: 363-367.

108 Burrows JA, Willis LK, Perlmutter DH: Chemical chaperones mediate increased secretion of mutant $\alpha 1$-antitrypsin $(\alpha 1$-AT) $Z$ : a potential pharmacological strategy for prevention of liver injury and emphysema in $\alpha 1-A T$ deficiency. Proc Natl Acad Sci USA 2000;97:1796-1801.

109 Devlin GL, Parfrey H, Tew DJ, Lomas DA, Bottomley SP: Prevention of polymerization of $\mathrm{M}$ and $\mathrm{Z} \alpha 1$-antitrypsin $(\alpha 1-\mathrm{AT})$ with trimethylamine $\mathrm{N}$-oxide: Implications for the treatment of $\alpha 1$-AT deficiency. Am J Respir Cell Mol Biol 2001;24:727-732.

110 Schmidt BZ, Perlmutter DH: Grp78, Grp94, and Grp170 interact with $\alpha 1$-antitrypsin mutants that are retained in the endoplasmic reticulum. Am J Physiol Gastrointest Liver Physiol 2005;289:G444-G455.

111 Chang YP, Mahadeva R, Chang WS, Shukla A, Dafforn TR, Chu YH: Identification of a 4-mer peptide inhibitor that effectively blocks the polymerization of pathogenic Z $\alpha 1$-antitrypsin. Am J Respir Cell Mol Biol 2006;35:540-548.

112 Mahadeva R, Dafforn TR, Carrell RW, Lomas DA: 6-mer peptide selectively anneals to a pathogenic serpin conformation and blocks polymerization. Implications for the prevention of $\mathrm{Z} \alpha_{1}$-antitrypsin-related cirrhosis. J Biol Chem 2002;277:6771-6774.

113 Parfrey H, Dafforn TR, Belorgey D, Lomas DA, Mahadeva R: Inhibiting polymerization: new therapeutic strategies for $Z \alpha 1$ antitrypsin-related emphysema. Am J Respir Cell Mol Biol 2004;31:133-139.
114 Kay MA, Baley P, Rothenberg S, Leland F, Fleming L, Ponder KP, Liu T, Finegold M, Darlington G, Pokorny W, et al: Expression of human $\alpha 1$-antitrypsin in dogs after autologous transplantation of retroviral transduced hepatocytes. Proc Natl Acad Sci USA 1992;89:89-93.

115 Jaffe HA, Danel C, Longenecker G, Metzger M, Setoguchi Y, Rosenfeld MA, Gant TW, Thorgeirsson SS, Stratford-Perricaudet LD, Perricaudet M, et al: Adenovirus-mediated in vivo gene transfer and expression in normal rat liver. Nat Genet 1992;1:372-378.

- 116 Rosenfeld MA, Siegfried W, Yoshimura K, Yoneyama K, Fukayama M, Stier LE, Paakko PK, Gilardi P, Stratford-Perricaudet LD, Perricaudet M, et al: Adenovirus-mediated transfer of a recombinant $\alpha 1$-antitrypsin gene to the lung epithelium in vivo. Science 1991;252:431-434.

117 Morral N, Parks RJ, Zhou H, Langston C, Schiedner G, Quinones J, Graham FL, Kochanek S, Beaudet AL: High doses of a helper-dependent adenoviral vector yield supraphysiological levels of $\alpha 1$-antitrypsin with negligible toxicity. Hum Gene Ther 1998;9:2709-2716.

118 Schiedner G, Morral N, Parks RJ, Wu Y, Koopmans SC, Langston C, Graham FL, Beaudet AL, Kochanek S: Genomic DNA transfer with a high-capacity adenovirus vector results in improved in vivo gene expression and decreased toxicity. Nat Genet 1998;18:180-183.

119 Kay MA, Graham F, Leland F, Woo SL: Therapeutic serum concentrations of human $\alpha$-1-antitrypsin after adenoviral-mediated gene transfer into mouse hepatocytes. Hepatology 1995;21:815-819.

120 Lu Y, Choi YK, Campbell-Thompson M, Li C, Tang Q, Crawford JM, Flotte TR, Song S: Therapeutic level of functional human $\alpha 1$ antitrypsin (hAAT) secreted from murine muscle transduced by adeno-associated virus (rAAV1) vector. J Gene Med 2006;8: 730-735.

121 Song S, Embury J, Laipis PJ, Berns KI, Crawford JM, Flotte TR: Stable therapeutic serum levels of human $\alpha-1$ antitrypsin (AAT) after portal vein injection of recombinant adeno-associated virus (rAAV) vectors. Gene Ther 2001;8:1299-1306.

122 Song S, Morgan M, Ellis T, Poirier A, Chesnut K, Wang J, Brantly M, Muzyczka N, Byrne BJ, Atkinson M, Flotte TR: Sustained secretion of human $\alpha$-1-antitrypsin from murine muscle transduced with adeno-associated virus vectors. Proc Natl Acad Sci USA 1998;95:14384-14388.

123 Alino SF, Crespo J, Bobadilla M, Lejarreta M, Blaya C, Crespo A: Expression of human $\alpha 1$-antitrypsin in mouse after in vivo gene transfer to hepatocytes by small liposomes. Biochem Biophys Res Commun 1994;204: 1023-1030. 
-124 Canonico AE, Conary JT, Meyrick BO, Brigham KL: Aerosol and intravenous transfection of human $\alpha 1$-antitrypsin gene to lungs of rabbits. Am J Respir Cell Mol Biol 1994;10:24-29.

125 AAT Deficiency Gene Transfer Research Study. http://www.alphaone.ufl.edu/gene_ study.php (accessed 2007).

-126 Zhou QJ, Xiang LX, Shao JZ, Hu RZ, Lu YL, Yao H, Dai LC: In vitro differentiation of hepatic progenitor cells from mouse embryonic stem cells induced by sodium butyrate. J Cell Biochem 2007;100:29-42.
127 Moriya K, Yoshikawa M, Saito K, Ouji Y, Nishiofuku M, Hayashi N, Ishizaka S, Fukui H: Embryonic stem cells develop into hepatocytes after intrasplenic transplantation in CCl4-treated mice. World J Gastroenterol 2007; 13:866-873.

128 Saito K, Yoshikawa M, Ouji Y, Moriya K, Nishiofuku M, Ueda S, Hayashi N, Ishizaka S, Fukui H: Promoted differentiation of cynomolgus monkey ES cells into hepatocyte-like cells by co-culture with mouse fetal liver-derived cells. World J Gastroenterol 2006;12:6818-6827.
129 Wang D, Haviland DL, Burns AR, Zsigmond E, Wetsel RA: A pure population of lung alveolar epithelial type II cells derived from human embryonic stem cells. Proc Natl Acad Sci USA 2007;104:4449-4454.

130 International HapMap Project. http://www. hapmap.org/ (accessed 2006).

131 International HapMap Consortium: A haplotype map of the human genome. Nature 2005;437:1299-1320. 